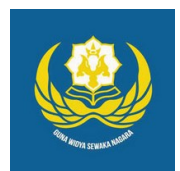

Jurnal Analogi Hukum

Journal Homepage: https://ejournal.warmadewa.ac.id/index.php/analogihukum

\title{
Ekstradisi Sebagai Upaya Pencegahan Dan Pemberantasan Kejahatan Internasional
}

\author{
Dwi Melia Nirmalananda Dewi*, I Made Sepud dan I Nyoman Sutama \\ Universitas Warmadewa, Denpasar-Bali, Indonesia \\ *made.setyarini@gmail.com
}

\begin{abstract}
How To Cite:
Setyarini, D, M., Mahendrawati, N, L, M., Arini, D, G, D.(2019). Ekstradisi Sebagai Upaya Pencegahan Dan Pemberantasan Kejahatan Internasiona. Jurnal Analogi Hukum. 2 (1). 17-21. Doi: http://dx.doi.org/10.22225/.2.1.1610.17-21
\end{abstract}

\begin{abstract}
The presence of a person to a country to escape resulted in the creation of many criminal crimes on an international scale, this requires special treatment, such as the existence of an international agreement, one of which is Extradition. Then it must be reviewed in advance regarding regulation and then move on to understanding the practice of extradition in preventing and combating international crime. The problems in this study are first, how is the regulation of extradition in preventing and combating international crime, second, how is the practice of extradition between countries in preventing and combating international crime. The research method used is a type of Normative research by using a statutory approach, conceptual approach and case approach which are analyzed using systematic techniques by being presented descriptively-analytically assisted with primary, secondary and tertiary legal sources which are collected and then interpreted. Focused on understanding and fulfilling the principles and procedures for compliance with international laws and conventions governing extradition and also focusing on cooperation between interested countries, in collaboration with ICPO-INTERPOL and NCB-INTERPOL who are competent in carrying out extradition.
\end{abstract}

Keywords: Between Countries, Extradition, International Crime.

\begin{abstract}
Abstrak-Kehadiran seseorang ke suatu negara untuk melarikan diri mengakibatkan terciptanya banyak kejahatan-kejahatan pidana dengan skala internasional, ini membutuhkan penanganan khusus, seperti adanya perjanjian internasional salah satunya Ekstradisi. Maka wajiblah dikaji terlebih dahulu mengenai pengaturan lalu beranjak ke pemahaman praktek ekstradisi dalam mencegah dan memberantas kejahatan internasional. Adapun permasalah yang didapat dalam penelitian ini pertama, bagaimanakah pengaturan ekstradisi dalam mencegah dan memberantas kejahatan internasional, kedua, bagaimanakah praktek ekstradisi antar negara dalam mencegah dan memberantas kejahatan internasional. Metode penelitian yang digunakan merupakan tipe penelitian Normatif dengan melakukan pendekatan perundang-undangan, pendekatan konseptual dan pendekatan kasus yang dianalisis menggunakan teknik bersifat sistematis dengan disajikan secara deskriptifanalitis dibantu dengan sumber bahan hukum primer, sekunder dan tersier yang dikumpulkan lalu ditafsirkan. Difokuskan kepada pemahaman dan pemenuhan prinsip-prinsip serta tatacara pelaksanaan sesuai UndangUndang dan konvensi Internasioal yang mengatur tentang Ekstradisi dan difokuskan pula kepada kerjasama antar negara yang berkepentingan, bekerjasama dengan ICPO-INTERPOL dan NCB-INTERPOL yang berkompeten dalam melaksanakan ekstradisi.
\end{abstract}

Kata Kunci: Antar Negara, Ekstradisi, Kejahatan Internasional.

\section{Pendahuluan}

Negara Republik Indonesia merupakan subjek hukum internasional yang mempunyai wilayah yang jelas batas-batasnya, dan mempunyai pemerintahan sendiri yang akan selalu beriringan dengan hukum pidana internasional maupun hukum perdata internasional dalam memperluas hubungan antar negara dalam rangka mewujudkn cita-cita bangsa sesuai alinea keempat Pembukaan Undang-Undang Dasar Negara Republik Indonesia Tahun 1945. Pengaruh dari perkembangan IPTEK yang bersifat dinamis berdampak pada kejahatan di dunia, yang memunculkan kejahatan-kejahatan yang terjadi melintasi batas teritorial suatu negara (Kalalo, 2016). Kejahatan yang muncul perlu diatasi dengan aturan hukum yang berlaku dan efektif 
(Atmasasmita, 1995). Namun terjadinya perbedaan hukum negara- negara didunia menjadi kendala dalam pencegahan dan pemberantasan terhadap kejahatan pidana yang dilakukan dengan dimensi Internasional. Perbedaan ini disebabkan karena setiap Negara yang berdaulat mempunyai Yuridiksi Kriminal berdasarkan Asast Teritorial yang sepenuhnya memiliki kedaulatan territorial atau yuridiksi teritorial (territorial sovereignty) (Parthiana, 2015).

Suatu Negara berdasarkan yuridiksi teritorial meemiliki hak, kekuasaan, atau kewenangan untuk membuat atau menetapkan peraturan perundang-undangan atau keputusankeputusan untuk diberlakukan dalam batas teritorialnya, dilaksanakan terhadap orang dana tau badan badan hukum serta mengadili pelaku kejahatan dimuka penegak hukum yang berwenang dalam teritorialnya (Parthiana, 2015). Akan tetapi, tidak dapat sering dilakukan dikarenakan pelaku kejahatan telah melarikan atau disebut fugitive ke yuridiksi territorial negara lain (Anwar, 2011). Maka dari itu, suatu negara tidak dapat secara semena-mena melaksanakan penegakan hukumnya yang bersifat kedaulatan diwilayah negara lain (Starke, 1989). Aparat penegak hukum suatu negara ketika penangkapan pelaku kejahatan hampir mustahil atau sulit dilakukan karena yuridiksi teritorialnya, maka suatu kerjasama antara aparat penegak hukum setiap negara merupakan salah satu solusi yang memungkinkan untuk mencegah dan memberantas pelaku kejahatan yang melarikan diri. Apparat penegak hukum setiap negara yang dimaksud adalah Internasonal Criminal Police Organisation (ICPO-INTERPOL) yang meamanatkan National Central Bureau (NCBINTERPOL) sebagai instansi yang berada di setiap negara anggota yang mempunyai tujuan untuk meminimalisasi hambatan yuridiksi teritorial tersebut dalam mencegah dan memberantas kejahatan di dunia (Widyawati, 2014).

Kerjasama Internasional dalam keadaan tersebut dipilih oleh pengambil keputusan setiap negara demi kepentingan bersama dalam mencegah, memberantas kejahatan di dunia sekaligus menegakan hukum, ketertiban dan keadilan, ini ditekankan kedalam Pasal 11 Ayat (1), (2) dan (3) Undang-Undang Dasar Negara Republik Indoneisa Tahun 1945. Maka suatu Kerjasama untuk mengatasi yuridiksi territorial sebagai penghambat, dalam konteks mencari, menangkap, menahan, dan menyerahkan pelaku kejahatan yang melarikan diri, dikenal dengan istilah Ekstradisi yang secara singkat diartikan sebagai pranata hukum yang mandiri berupa praktik-praktik tentang pengambilan dan penyerahan atau membawa kembali seorang pelaku kejahatan dari suatu negara yang merupakan tempatnya melarikan diri dan mencari perlindungan ke negara lain yang memiliki yurisdiksi criminal (Sunarso, 2009).

Berdasarkan atas dasar pemikiran tersebut, maka dapat dikaji lebih lanjut dengan menelaah permasalahan yaitu pertama, bagaimanakah pengaturan ekstradisi dalam mencegah dan memberantas kejahatan internasional, kedua, bagaimanakah praktek ekstradisi antar negara dalam mencegah dan memberantas kejahatan internasional. Dengan tujuan mengidentifikasi dan menjelaskan pengaturan dan Menganalisis Praktek Ekstradisi antar Negara dalam Mencegah dan Memberantas Kejahatan Internasional, serta sebagai referensi tambahan bagi yang berminat dalam bidang kajian yang sama dan pendukung dalam pengembangan pemikiran konseptual pada bidang yang sama.

\section{Metode}

Penelitian ini bertolak kepada menggunakan tipe penelitian normatif yang disebut juga penelitian hukum doctrinal. Alasan menggunakan tipe penelitian ini dikarenakan terjadi kekaburan norma untuk menegaskan lebih lanjut Undang-Undang Ekstradisi yang dalam penjelasanan mekanisme dan pelaksanaan pemrmintaan ekstradisi dari Indonesia ke negara lain yang mana akan diatur dengan Peraturan Pemerintah. Akan tetapi sampai saat ini, mandat yuridis formal yang ditetapkan Undang-Undang Ekstradisi tentang Ekstradisi sesuai Pasal 46 Undang-Undang No 1 Tahun 1979 yang telah menegaskan bahwa tata acara permintaan penyerahan dan penerimaan seseorang yang diserahkan kepada Pemerintahan Republik Indonesia akan diatur dengan Peraturan Pemerintah (PP). Namun dalam kenyataannya Pemerintahan Republik Indonesia telah banyak membuat UndangUndang tentang Ekstradisi khususnya dengan negara-negara Asean, baik yag sudah diratifikasi ke dalam Undang-Undang, maupun ada yang belum diratifikasi. Dalam pelaksanaan ekstradisi di Indonesia baik sebagai Pihak Peminta maupun Pihak Diminta, lebih banyaj memanfaatkan kebiasaan yang selama ini dijalankan, dengan melalui sarana ICPOINTERPOL. Tipe penelitian ini merupakan penelitian yang berfokus pada masalah yang meneliti masalah didasarkan pada teori. Dari sudut ilmu yang dipergunakan dalam penelitian ini bersifat monodisipliner dalam arti bahwa ada satu disiplin ilmu yang digunakan yaitu 
ilmu hukum.

Pendekatan masalah dalam penelitian ini dilakukan dengan mempergunakan metode pendekatan perundang-undangan dengan menelaah semua undang-undang dan regulasi yang bersangkut paut dengan peristiwa hukum yang terkait, pendekatan konseptual yang beranjak dari pandangan-pandangan dan doktrin -doktrin yang berkembang di dalam ilmu hukum ditunjang dengan pendekatan kasus. Untuk memperoleh bahan-bahan hukum primer, sekunder dan tersier digunakan teknik inventarisasi atau penelusuran bahan hukum yang bersangkutan lalu di klasifikasi atau dikelompokan dan didokumentasikan, dicatat, dikutip, diringkas, diulas sesuai kebutuhan dengan pendekatan kualitatif.

Menganalisis penelitian ini menggunakan teknik bersifat sistematis dengan disajikan secara deskriptif-analitis, yaitu dengan mendeskripsikan bahan hukum terlebih dahulu secara sistematis kemudian menganalisa melalui teknik analisis dengan teknik tafsiran dan menggunakan argumentasi yang bertumpu pada logika hukum dengan deduktif-induktif.

\section{Hasil Penelitian Dan Pembahasan}

\section{Pengaturan Ekstradisi dalam Mencegah dan Memberantas Kejahatan Internasional}

Ekstradisi penting dalam hal mencegah dan memberantas kejahatan didunia yang dihadapi tidak hanya oleh Indonesia karena semakin meningkatnya jumlah pelaku yang melarikan diri. Dalam mengatasi dibutuhkan kerjasama antar negara dengan Ekstradisi sebagai Penghubungnya. Dalam konteks hubungan antar bangsa, Ekstradisi sebagai mekanisme dalam mencegah dan memberantas kejahatan internasional.

Agar ekstradisi bisa terlaksana dengan baik, harus memperhatikan prinsip-prinsip yang terdapat dalam perjanjian ekstradisi yang diselenggarakan pemerintah Republik Indonesia tercantum dalam Undang-Undang Nomor 1 Tahun 1979 Tentang Ekstradisi, yaitu: Ekstradisi atas dasar Perjanjian dan Ekstradisi atas dasar Hubungan Baik atau Treaty and Agreement (Pasal 2 Ayat (1) dan (2) UndangUndang Ekstradisi), Prinsip Kejahatan Rangkap atau Double Criminality (Pasal 4 Ayat (1) dan (2) Undang-Undnag Ekstradisi), Prinsip Tidak menyerahkan Pelaku Politik atau Non Extradition of Political Criminal (Pasal 5 Ayat (1), (2), (3), dan (4) Undang-Undang Ekstradisi), Prinsip Tidak Menyerahkan Warga
Negara atau Non Extradition Nationality (Pasal 7 Ayat (1) Undnag-Undang Ekstradisi), Prinsip Tempat Melakukan Kejahatan atau Lex Loci Delictus (Pasal 8 Undang-Undang Ekstradisi), Prinsip Penolakan Ekstradisi karena Orang yang diminta sedang diproses di Indonesia (Pasal 9 Undang-Undang Ekstradisi), Prinsip Non bis in idem (Pasal 10 Undang-Undang Ekstradisi), Prinsip Kedaluwarsa (Pasal 12 Undang-Undang Ekstradisi), Prinsip Capital Punishment (Pasal 13 Undang-Undang Ekstradisi), Prinsip Penolakan Ekstradisi Karena Ada Sangkaan Yang Cukup Kuat (Pasal 14 Undang-Undang Ekstradisi, Prinsip Kekhususan atau Specially (Pasal 15 UndangUndang Ekstradisi), Prinsip Penolakan Ekstradisi karena Orang yang diminta akan di Ekstradisikan kepada Pihak ketiga (Pasal 16 Undnag-Undang Ekstradisi), dan Prinsip Permintaan yang Ditunda Pemenuhannya (Pasal 17 Undang-Undang Ekstradisi).

Dalam disistem Pidana menunjukkan gambaran bahwa pada umumnya ekstradisi terdapat dua model yaitu berdasarkan hanya atas hubungan baik atau non treaty dan berdasarkan perjanjian ekstradisi atau extradition treaty. Kerjasama Internasional sebagai pencegahan dan pemberantasan kejahatan di dunia dalam hal ini dikenal bebrapa perjanjian internasional, antara lain, Memorandum of Understanding (MoU), Mutual Legal Assistance (MLA), Ekstradisi dan Transfer of Sentenced Person (Perjanjian pemindahan orang yang sudah dihukum) (Husein, 2006).

Dalam Hukum Internasional terdapat dua konvensi yang dapat dikatakan memberikan landasan bagi pengembangan ekstradisi sebagai instrument kerjasama penegakan hukum, pencegahan dan pemberantasan kejahatan adalah Konvensi PBB tentang Kejahatan Transnasional (United Nations Convention against Transnational Organized Crime , disingkat UNTOC) yang ditandatangani di Palermo, Italia pada tahun 2000 dan Konvensi PBB tentang Anti Korupsi (United Nations Convention against Corruption, disingkat UNCAC) yang ditandatangani di Merida, Meksiko pada tahun 2003.Kedua Konvensi Internasional tersebut merupakan tonggak perkembangan ekstradisi sebagai Instrumen dalam Upaya Penegakan Hukum mengingat jumlah negara yang menandatangani dan meratifikasi kedua Konvensi terbilang cukup besar, Kedua Konvensi Internasional menyatakan bahwa dalam hal sebuah negara mengatur ekstadisi hanya dapat dilaksanakan berdasarkan perjanjian, maka negara tersebut 
pada saat ratifikasi konvensi tersebut, dapat menganggap konvensi tersebut sebagai perjanjian ekstradisi dengan negara-negara pihak lainnya. Di dalam UNTOC masalah ekstradisi diatur di dalam Pasal 16 dan masalah ekstradisi diatur dalam Pasal 44 UNCAC.

\section{Praktek Ekstradisi Dalam Mencegah Dan Memberantas Kejahatan Internasional}

Kejahtaan Ekstradisi yang dimintakan dapat dikabulkan jika terhadap kejahatan tersebut terdapat dalam lampiran daftar kejahatan yang tercantum dalam UndangUndnag Ekstradisi atau atas dasar kebijaksanaan dari negara-diminta. Dalam memproses ekstradisi ada tatacara yang harus diikuti dalam penegakan hukum, perlindungan Hak Asasi Manusia (HAM) sekaligus pencegahan dan pemberantasan Kejahatan Internasional yang mana setiap kedudukan negara sebagai subyek memiliki tatacara yang berbeda dalam memproses Ekstradisi. Proses Ekstradisi saat kedudukan Indonesia sebagai Negara Diminta, yaitu: diterimanya Permintaan Penahanan dan Penangkapan; dilakukan Penangkapan dan Penahanan Sementara; perpanjangan Penangkapan dan Penahanan; Permintaan Ekstradisi; Proses pemeriksan di pengadilan; Proses pengambilan Keputusan dan Pelaksanaan Ekstradisi (Maringka, 2018). Sedangkapn Proses Ekstradisi saat kedudukan Indonesia sebagai Negara Peminta, yaitu: permintaan pencarian sekaligus penangkapan dan penahanan; penyiapan persyaratan permintaan Ekstradisi, Pemeriksaan Permintaan oleh Mentri Hukum dan HAM; diperiksa dan di kirim secara formal oleh Menteri Luar Negeri kepada Negara Diminta (bagi yang telah memiliki Perjanjian), dikirim secra formal melalui saluran diplomatic NCB-INTERPOL Negara-Diminta (bagi yang tidak memiliki Perjanjian); Pemeriksaan dipengadilan di Negara-Diminta; Putusan Pengadilan; disalurkan ke Menteri Kehakiman di Negara Diminta; pelaksanaan Ekstradiis (Sunarso, 2009). Dalam satu Kasus dimana Negara Republik Indonesia sebaga Negara-Diminta dan Negara Republik Federal Jerman sebagai Negara-Peminta yang belum mempunyai perjanjian Ekstradisi, Ektradisi oleh Negara republic Indonesia dikabulkan dikarenakan telah memenuhi syarat dan tidka menyimpang dari prinsip dan kaidah yang harus diperhatikan. Ekstradisi dikabulakn dengan berdasarkan hubungan baik (Jendra, 2018). Pelaksanaan Ekstradisi dalam kasus ini, pelaksanaan Ekstradisi dapat terlaksana dengan baik dikarenakan setiap pihak bekerja sama dengan baik, pihak yang mengupayakan terlaksananya pencegahan dan pemberantasan kejahatan internasional adalah ICPO-INTERPOL dan NCB-INTERPOL disetiap Negara (Jendra, 2018), yang menyalurkan pengumuman tentang Daftar Pencarian Orang atau disebut dengan Red Notice yang merupakan salah satu upaya pemberantasan kejahatan Internaional (Widyawati, 2014).

\section{Simpulan}

Berdasarkan uraian dalam pembahasan, dapat dibuat simpulan, sebagai berikut: Pengaturan Ekstradisi dalam mencegah dan memberantas kejahatan Internasional harus memperhatikan prinsipprinsip Ekstradisi yang terdapat dalam UndangUndang Ekstradisi yang tercantum dalam $\mathrm{BAB}$ II tentang azas-azas Ekstradisi dari Pasal 2 s.d Pasal 17 Undang-Undang No. 1 Tahun 1979 Tentang Ekstradisi. Dalam system pidana menunjukan gambaran bahwa pada umumnya ekstradisi terdapat dua model yaitu berdasarkan hanya atas perjanjian ekstradisi (extradition treaty) dan berdasarkan hubungan baik (non treaty). Dalam bidang pidana terdapat bentuk perjanjian kerjasama selain Ekstradisi yaitu Memorandum of Understanding (MoU) Mutual Legal Assistence (MLA) dan Transfer of Sentenced Prisoners. Dalam perkembangan ekstradisi, Konvensi yang mendorong efektifitas ekstradisi yang dapat dikatakan memberikan landasan bagi pengembangan ekstradisi adalah Konvensi PBB tentang Kejahatan Transnasional disingkat UNTOC khususnya Pasal 16 dan Konvensi PBB tentang Anti Korupsi disingkat UNCAC khususnya Pasal 44.

Praktek Ekstradisi dalam mencegah dan memberantas kejahtan Internasional harus dilaksanakan secara formal mengikuti proses Ekstradisi sesuai kedudukan Negara. Proses Ekstradisi saat kedudukan Indonesia sebagai Negara Diminta, yaitu: diterimanya Permintaan Penahanan dan Penangkapan; dilakukan Penangkapan dan Penahanan Sementara; perpanjangan Penangkapan dan Penahanan; Permintaan Ekstradisi; Proses pemeriksan di pengadilan; Proses pengambilan Keputusan dan Pelaksanaan Ekstradisi. Sedangkan Proses Ekstradisi saat kedudukan Indonesia sebagai Negara Peminta, yaitu: permintaan pencarian sekaligus penangkapan dan penahanan; penyiapan persyaratan permintaan Ekstradisi; diperiksa dan di kirim secara formal oleh Menteri Luar Negeri kepada Negara Diminta (bagi yang telah memiliki Perjanjian), dikirim secara formal melalui saluran diplomatic NCB- 


\begin{abstract}
INTERPOL Negara-Diminta (bagi yang tidak memiliki Perjanjian); Pemeriksaan dipengadilan di Negara-Diminta; Putusan Pengadilan; disalurkan ke Menteri Kehakiman di Negara Diminta; Pelaksanaan Ekstradiis. Dalam pelaksanaan Ekstradisi pihak yang mengupayakan terlaksananya pencegahan dan pemberantasan kejahatan internasional adalah ICPO-INTERPOL dan NCB-INTERPOL disetiap Negara, yang menyalurkan pengumuman tentang Daftar Pencarian Orang (DPO) atau disebut dengan Red Notice serta memberikan pelayanan bantuan penyidikan dan pertukaran data dan informasi dalam tugasnya menanggulangi dan memberantas kejahatan yang melewati batas wilayah negara.
\end{abstract}

\section{Daftar Pustaka}

Anwar, K. (2011). Hukum Internasional II. Bandar Lampung: Universitas Lampung.

Atmasasmita, R. (1995). Pengantar Hukum Pidana Indonesia. Bandung: PT. Eresco.

Husein, Y. (2006). Makalah Seminar Tentang Bantuan Timbal Balik dalam Masalah Pidana. Bandung: BPHN.

Jendra, I. N. (2018). Penetapan Perkara Ekstradisi, Nomor 02/PidEx/2017/ PNDps.

Kalalo, F. P. (2016). Efektifitas Perjanjian Sebagai Sarana Pencegahan, Pemberantasaan Dan Penghukuman Pelaku Tindak Pidana Internasional. Lex et Societatis, 4(1).

Maringka, J. S. (2018). Ekstradisi dalam Sistem Peradilan Pidana. Jakarta: Sinar Grafika.

Parthiana, I. W. (2015). Hukum Pidana Internasional (Cet.II). Bandung: Yrawa Widya.

Starke, J. G. (1989). Pengantar Hukum Internasional. Jakarta: Sinar Grafika.

Sunarso, S. (2009). Ekstradisi Dan Bantuan Timbal Balik Dalam Masalah Pidana Instrumen Penegakan Hukum Pidana Internasional. Jakarta: Rineka Cipta.

Widyawati, A. (2014). Pengantar Hukum Pidana. Jakarta: Sinar Grafika. 